\title{
Removable partial denture with attachment as a treatment option in pa- tients with cleft lip and palate
}

\author{
Prótese parcial removivel com encaixe como opção de tratamento em paciente com fissura labiopalatina
}

Marianne Barbosa Salgado de OLIVEIRA'

Maria Giulia Rezende PUCCIARELLI ${ }^{1}$

José Fernando Scarelli LOPES'

Rafael D'Aquino TAVANO'

\begin{abstract}
The rehabilitation treatment of patients with cleft lip and palate is lengthy and is carried out by various professionals from different areas of healthcare. To this end, planning and specialist knowledge are critical to the success of the treatment, in this way envisioning the aesthetic and functional rehabilitation of the individual in order to integrate them into society. This study consists of a literature review along with the report of a clinical case, demonstrating the treatment performed with the use of a removable partial denture using the abutment teeth treated with milled metal-ceramic crowns and the use of attachments, with a view to promoting the retention and stability of the prosthetic device. With the use of this system as a whole, aimed at improving the facial proportions due to the restoration of vertical dimension of occlusion and adequate lip support, features that are often not present in individuals with cleft lip and palate. In this work, we are seeking to underline the importance of scientific and technical knowledge, combined with a well-executed planning, in order to achieve successful treatment that restores function and aesthetics to the patient, thereby enabling their reintegration into society.
\end{abstract}

Indexing terms: Crowns. Dental prosthesis design. Mouth rehabilitation.

\section{RESUMO}

O tratamento reabilitador de um paciente com fissura labiopalatina envolve um longo período e efetuado por diversos profissionais de diferentes áreas da saúde. Para tal, o planejamento e o conhecimento específico são de suma importância para o sucesso do tratamento, vislumbrando, dessa forma, a reabilitação estética e funcional do indivíduo de forma a integrá-lo na sociedade. O presente trabalho consiste em relato de um caso clínico, demonstrando o tratamento efetuado com a utilização de prótese parcial removível utilizando os dentes pilares tratados com coroas metalo-cerâmicas fresadas e a utilização de encaixes, com intuito de favorecer a retenção e estabilidade do aparelho protético. Com o uso de todo esse sistema objetivando a melhoria nas proporções faciais devido à devolução da dimensão vertical de oclusão e suporte labial adequado, características que muitas vezes não estão presentes nos indivíduos com fissuras labiopalatinas. Este trabalho tem o intuito de ressaltar a importância do conhecimento científico e técnico, somados a planejamento bem realizado a fim de se conseguir o sucesso do tratamento, devolvendo função e estética do paciente, reintegrando-o a sociedade.

Termos de indexação: Coroas dentárias. Planejamento de prótese dentária. Reabilitação bucal.

\section{INTRODUCTION}

Cleft lip and palate is one of the most common facial deformities found in human beings, and it manifests itself in different forms and to different extents, which stem from the failure of the lip and/or palate to close. They can be unilateral or bilateral, and may appear in various forms (lip only, lip and palate, or uvula). The cleft is caused by a multitude of factors and, occasionally by a combination of genetic and environmental factors. The treatment is multidisciplinary, involving the fields of dentistry, plastic surgery and speech therapy ${ }^{1}$.

Patients with bilateral cleft lip and palate present several challenges to the success of dental treatment. These include mobility of the premaxilla, absence and/or poor positioning of the anterior teeth, unfavorable soft tissue, e.g. tense upper lip. There are several options for prosthetic rehabilitation treatment, but the high prevalence of unsuccessful maxillary bone grafts often makes the installation of dental implants impossible, hence the need for oral rehabilitation with a fixed prosthesis or removable partial denture².

Regarding treatment planning for oral rehabilitation, the occlusal vertical (OVD) is one of the first items to be analyzed. Changes in OVD also produce alterations in the freeway space (FS), which correspond to the difference between the OVD and the vertical dimension at rest (VDR). Reduced OVD may cause problems such as angular cheilitis and aesthetic facial imbalance ${ }^{3}$.

Therefore, with a complex oral rehabilitation, several factors must be considered in order to ascertain good treatment planning and achieve both aesthetic and

\footnotetext{
${ }^{1}$ Universidade de São Paulo, Hospital de Reabilitação de Anomalias Craniofaciais, Setor de Prótese Dentária. Rua Silvio Marchione, 3-20, Vila Universitária, 17012-900, Bauru, SP, Brasil. Correspondência para / Correspondence to: MBS OLIVEIRA. E-mail: <marianne_oliveira@hotmail.com>.
} 
functional outcomes. Such factors include the evaluation of the remaining teeth, lip support, vertical dimension, smile line, etc.

\section{CASE REPORT}

A 37-year-old female with surgically treated bilateral cleft lip and palate presented with a removable partial denture, which was causing her dissatisfaction with her appearance, mainly because the anterior teeth were barely visible when she smiled naturally (Figures 1 and 2). History and clinical examination were performed, and the following teeth were found to be missing: $18,16,12,11$, 21, 22, 23 and 28 (Figure 3). In addition, there was largescale bone resorption in the anterior region of her upper arch, which caused loss of lip support, and the lower third of the face was disproportionate, causing aesthetic and functional issues (Figure 4).

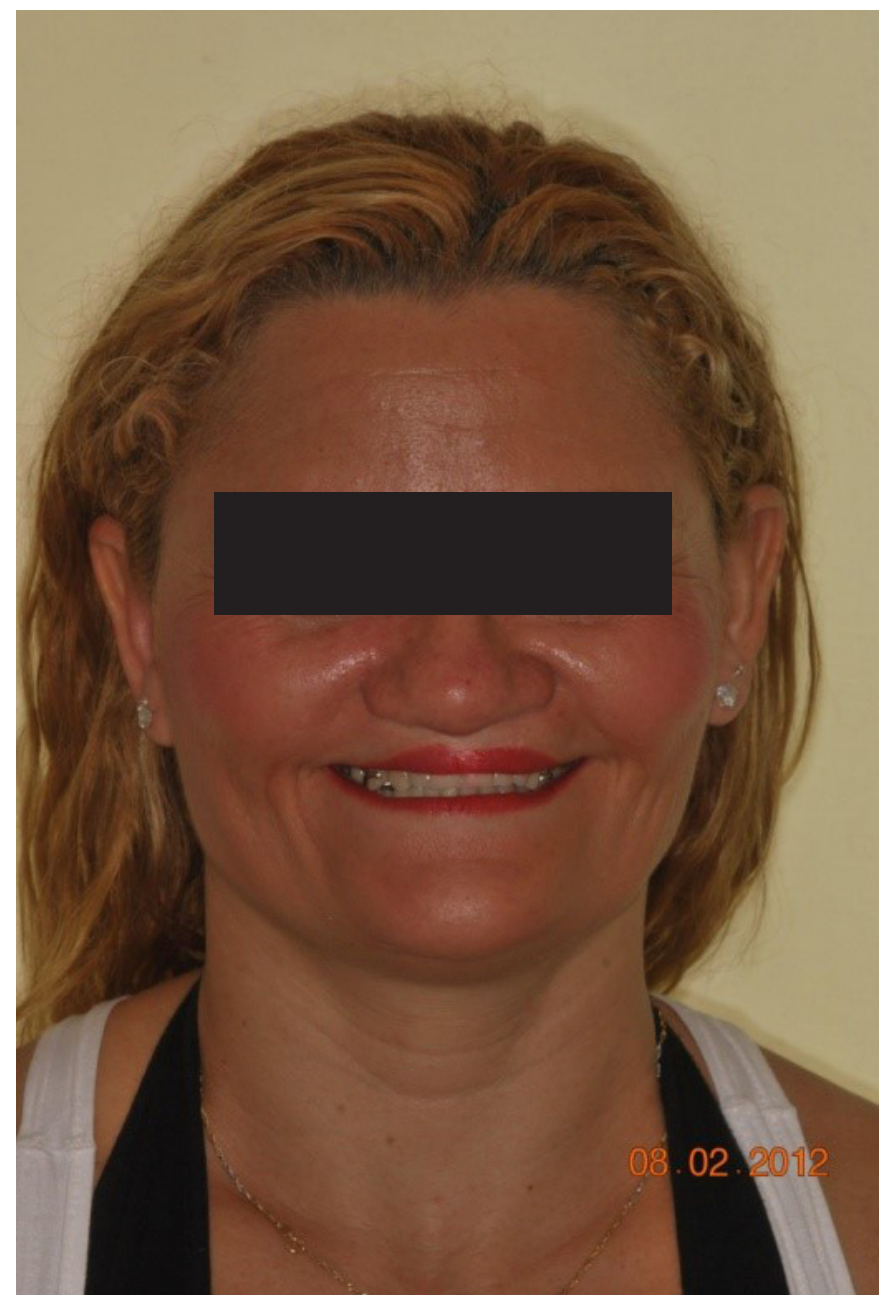

Figure 1. Front view of old RPD.

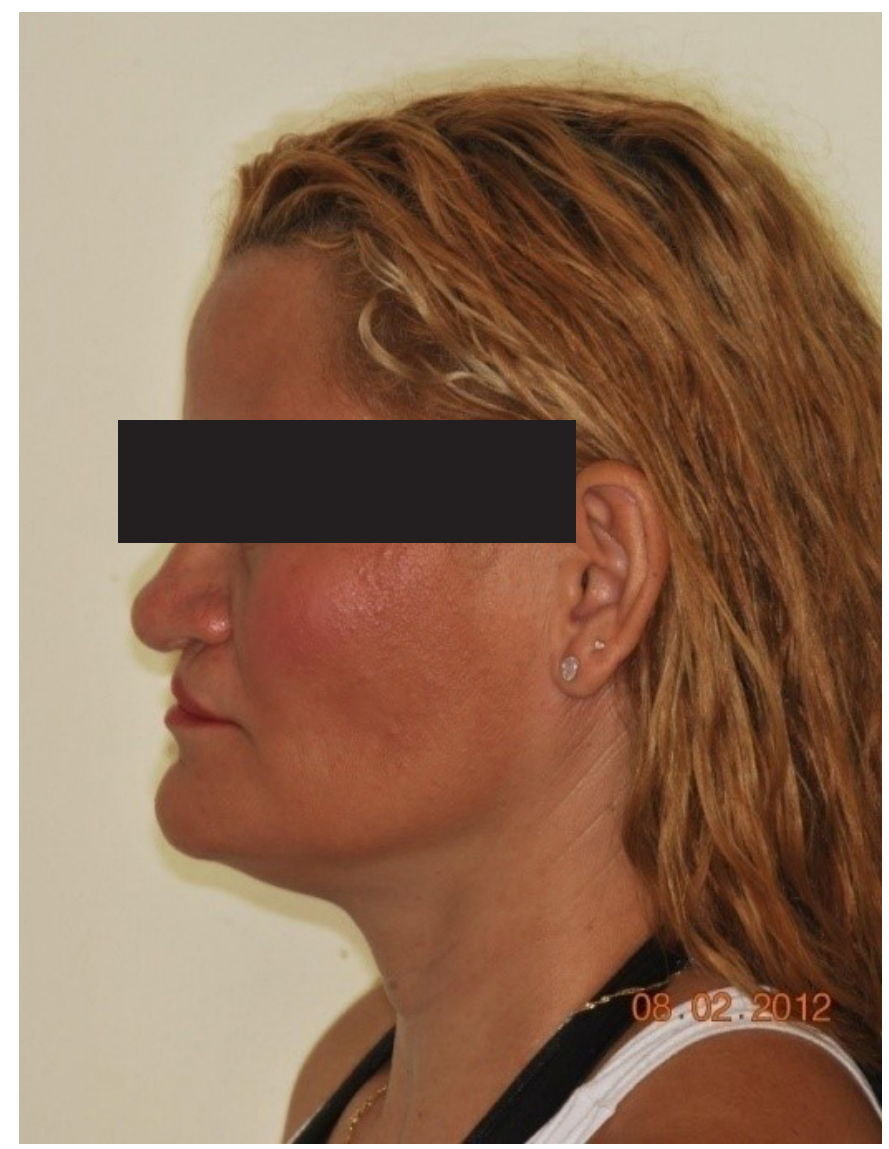

Figure 2. Side view of old RPD

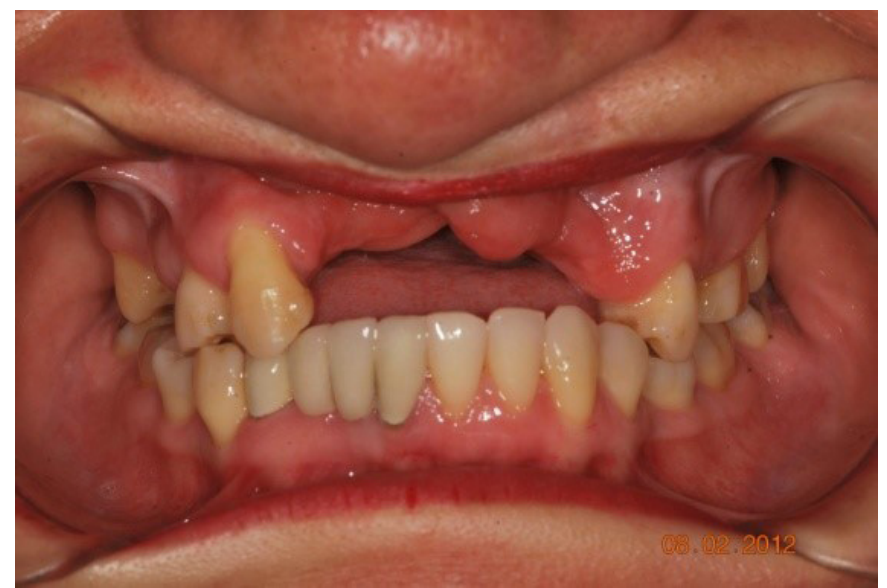

Figure 3. Anterior bone resorption: loss of OVD.

Following clinical, study models and radiographic analysis, oral rehabilitation was planned using a fixed partial prosthesis with milled crowns on the teeth selected as prosthetic abutments reestablishing the OVD, together with a removable partial denture with semi-precision attachment, aimed at providing lip support.

In order to carry out the preparation of the teeth, the silhouette technique was applied, consisting of wearing 
down one half of the tooth and then the other. To this end, the following diamond burs were employed: spherical (FG 1012) to make the cervical groove, cylindrical ogival end (FG 3216) for the guide grooves and definition of the end point, conical ogival end (3203 FG) to remove the natural convexity of the teeth on the mesial and distal walls and, lastly, flame (FG 3118) on the anterior teeth to wear down the palatal concavity. The following teeth were prepared: 17, 15, 14, 13, 24, 25 and 26 (Figure 5).

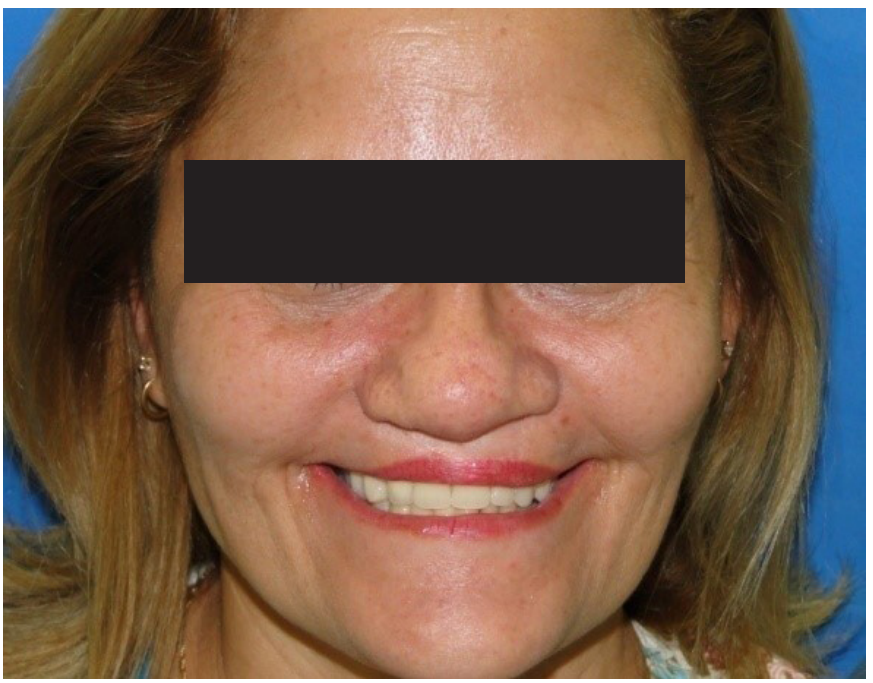

Figure 4. Temporary crowns.

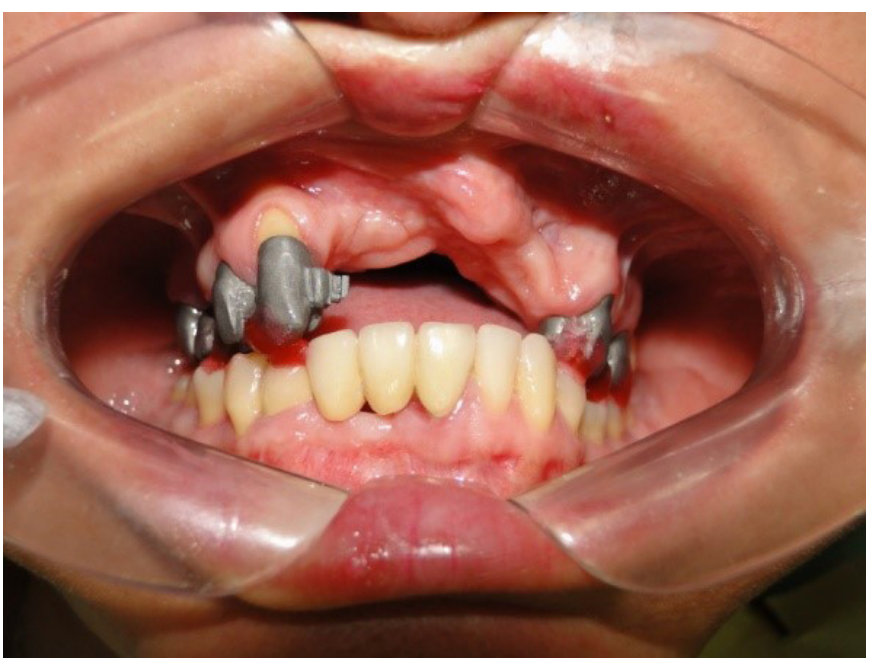

Figure 5. Metal-ceramic crown framework.

As it was necessary to restore the vertical dimension of occlusion, a control phase for the patient is required with this new measurement. For this purpose, the vertical dimension of occlusion was computed using the modified Lytle technique and, using a registration tray, it is possible to submit the new vertical dimension measurement to the laboratory, enabling the fabrication of overpressed temporary crowns. These were installed together with a removable denture, just for the patient's period of adaptation (Figure 6).

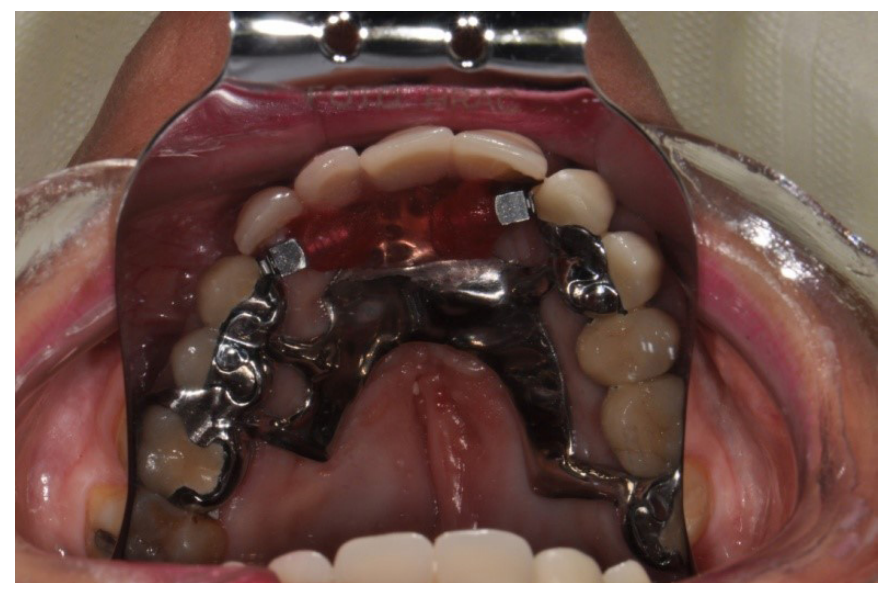

Figure $\mathbf{6 .}$. Try-in phase of the teeth and semi-precision attachments.

Once this period had elapsed, the molding was performed with transfer trays, using the molding material Impregum Soft (3M ESPE) to fabricate the metallic infrastructure of the metal-ceramic crown. Subsequently, the testing of the metal infrastructures was performed on one side of the arch, then occlusal registration with Duralay acrylic resin, maintaining the vertical dimension that was reestablished, holding in position the temporary crowns of the opposite side, and subsequently the testingand occlusal registration of the metallic infrastructure of the remainder of the arch (Figures 7 and 8), thereby permitting the molding for the reassembly and application of the porcelain.

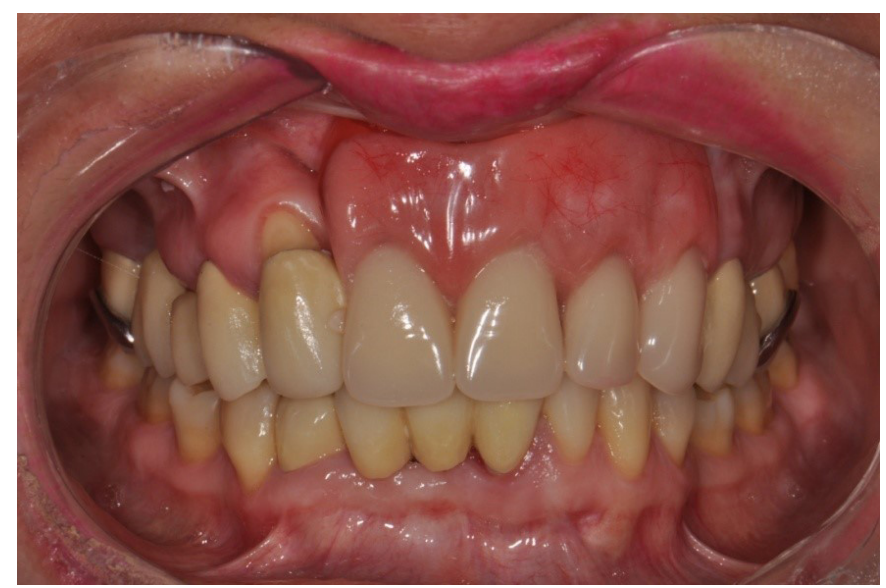

Figure 7. Cementation of crowns with RPD in place. 


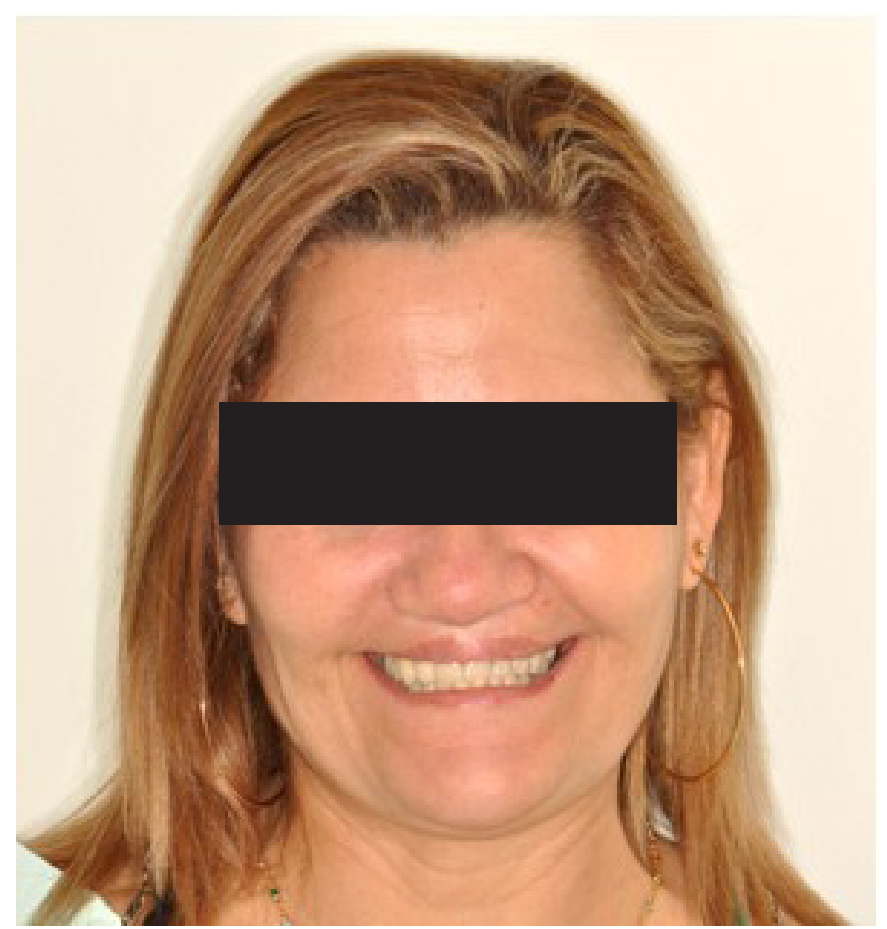

Figure 8. Final outcome.

Once mounted in a Semi-Adjustable Articulator, the application of the porcelain was carried out in the color A2 on the Vitta Scale. Then, the testing and adjustment of the porcelain was performed inside the patient's mouth, always paying attention to the reestablished vertical dimension measurement. Once the milled metal-ceramic crowns were ready, this permitted the molding in order to fabricate the metallic frame for the removable partial denture (RPD) with a semi-precision attachment.

With the metal-ceramic crowns in place inside the patient's mouth, the testing of the RPD's metal frame was carried out, and afterwards the wax rim, permitting lip support to return and to demarcate the reference lines (midline, smile line and canine line), using occlusal registration withenolic zinc paste.

Next, the testing was carried out of the teeth in wax, followed by the approval of the patient and the acrylization of the RPD. The capture of the semi-precision attachments was performed directly in the mouth to avoid any contraction of the acrylic resin and any maladjustment.

Then to finish off, the cementation of the milled metal-ceramic crowns was performed using the resin cement Rely X Luting 2 from 3M ESPE, with the simultaneous fitting of the RPD, which remained in place for 24 hours until the cement was completely set, preventing the crowns from moving and the RPD from failing to adapt.
Periodic checks were subsequently made, the patient having no complaints, apparently satisfied with the treatment. Comparing before and after photographs, it is possible to see the importance of the OVD and the change in the facial esthetics, reducing the signs of aging as well as restoring function.

The patient was given the Free and Informed Consent document, in accordance with the legal requirements, as well as a Permission Form for the use of the records (photographs, radiographs and the respective dental and medical reports, video images, voice samples, clinical records, photographs of organs and specimens) for research and teaching purposes, and the publication in scientific articles.

\section{DISCUSSION}

Cleft lip and palate occurs due to changes during fetal development. They affect the orofacial structures such as the upper lip, alveolar rim, hard palate, soft palate, nose and eyes ${ }^{1}$.

Bilateral cleftlip and palate is one of the most common and it ends up producing significant aesthetic, functional and psychological changes in the patient. Its treatment requires the involvement of professionals from a variety of disciplines, requiring the participation of all areas of dentistry as well as physicians, psychologists, speech therapists, among others. Currently, cleft lip and palate is the most commonly found congenital malformation in the maxillofacial region. Its etiology is multifactorial, and may suffer interference from genetic and/or environmental factors, but its formation is not precisely clear ${ }^{2}$. Patients born with clefts may have dental anomalies of shape, number, size and position, which leads us toperform a thorough case study and the most appropriate planning for each patient ${ }^{2}$.

In order to achieve a successful treatment outcome, it is necessary, in addition to multidisciplinary planning, to monitor the progress of the plan, where changes may take place if a procedure does not turn out as expected and also according to the desires and needs of the patient, which may also change over time ${ }^{4}$.

Fortunately, over the years, advances made in studies and technology have enabled better treatment options for patients with clefts. However, depending on the complexity of the case, rehabilitation treatment with prostheses is still required in the majority of cases $^{5}$.

Cleft patients have missing teeth, mainly in the 
region of the cleft and, for the purposes of rehabilitation, numerous possibilities exist that vary from patient to patient. Initially, the installation of dental implants might be evaluated, with or without the need for bone grafts, and failing this, it may be resolved with a fixed prosthesis, using abutments or evena removable partial denture ${ }^{6}$.

The treatment of patients with clefts begins in early childhood. As long as the dentition is well looked after and healthy during childhood, adolescence and adulthood, this helps the orthodontic surgical treatment, minimizing and improving the prosthetic effort. From the outset of initial consultation, monitoring by the entire multiprofessional teamis required in order to evaluate the treatment options on a case by case basis, examining the need for orthodontic intervention, perhaps keeping or reducing prosthetic spaces for the finalization of the treatment with fixed or removable prostheses or prostheses on implants, or even surgery 5 .

During clinical examinations, the structure of the remaining teeth should be observed as well as the aesthetics of the patient. Some patients have dental wear and tear, and when excessive, this can be one of the reasons for loss of vertical dimension of occlusion, leading to a need for prosthetic rehabilitation treatment to restore function and aesthetic appearance ${ }^{7}$. Moreover,other factors that can cause this wear and tear include: dental attrition due to excessive contact, parafunctional habits orloss of posterior teeth ${ }^{8}$. Once a patient needs to reestablish vertical dimension of occlusion, it is essential that he/she goes through a period of adaptation to these measures using temporary prostheses so that it can be confirmed, at this stage, if the patient's function and aesthetics were restored, in order to proceed with the definitive prosthesis?.

Once teeth are lost, this leads to bone resorption which can lead to loss of lip support, producing aesthetic and phonetic changes ${ }^{10}$. This produces a change in the lower third of the patient's face, as seen in the extraoral examination where, due to the loss of muscle tone and lines of expression, the patient appears to be older ${ }^{11}$. This can be restored using a removable partial denture, restoring lip support via an adjustment to the wax rim, consequently improving the patient's aged appearance.

To render a better aesthetic look, the system of attachments between the fixed prosthesis and removable partial denture was used.The attachment is a mechanical device that possesses the functions of fixing, retaining and stabilizing the removable partial denture, which acts as a direct retainer. Accordingly, it must offer support, retention, reciprocity, stability, fixation. One of the main indications for the use of attachments between fixed and removable partial prostheses is aesthetic appearance ${ }^{12}$.

Therefore, essential to the success of the clinical case is planning with the study of the models, extraoral and intraoral examinations of each clinical case, and studies based on scientific literature, in order to be able to perform a complete rehabilitation on the patient with cleft lip and palate, which seeks to restore function, phonetics, mastication, aesthetics and, consequently, reintegration into society. Even with the variety of treatment options available within prosthetic rehabilitation, where indications vary according to case, the cost/benefit of the patient's treatment should always be analyzed, while seeking to satisfy the main complaints and desires of the patient, and aiming to restore masticatory function. These treatment options include: prosthesis on implant, removable partial denture, fixed prosthesis and total prosthesis.

According to the clinical case reported, where the patient presents with a highdegreeof anterior bone resorption, leading to loss of lip support, the impossibility of fitting implants and performing bone grafts, and the presence ofseveral teeth, it was decided to use a removable partial denturewith semi-precision attachments with milled crowns on those teeth present, restoring vertical dimension of occlusion and, consequently, masticatory function, lip support and aesthetic appearance.

\section{CONCLUSION}

With the reported case and the peculiarities that cleft patients present, the importance of case planningcan be seen with the involvement of a multidisciplinary team, seeking to meet the patient's expectationsand restore his/her function and appearance, enabling his/her reintegration into society.

To this end, it is necessary to use scientific literature as a basis, in the quest for a better treatment plan, and constantly evaluate the respective cost/benefit.

\section{Collaborators}

JFS LOPES contributed with the planning of the clinical case, the sistematic review and the final approval of the article to be published. MGR PUCCIARELLI contributed with the clinical execution of the case. MBS OLIVEIRA was the responsible for writing and submission of the article. RD TAVANO was responsible of planning the clinical case and doing the photos. 


\section{REFERENCES}

1. Prahbu S, Rekha K, Maji J, Vishnudas P. Etiopathogenesis of orofacial cleftingrevisited. J Oral Maxilo Fac Pathol. 2012;16(2):228-32. doi: 10.4103/0973-029X.99074

2. Suedam I, Gaia B, Cheng C, Trindade P, Bastos J, Mattos B. Cleft lip and palate: recommendations for dental anesthetic procedure based on anatomic evidences. J Appl Oral Sci. 2012;20(1):122-7. doi: 10.1590/S1678-77572012000100021

3. Discacciati J, Souza E, Vasconcellos W, Costa, S, Barros V. Increased vertical dimension of occlusion: signs, symptoms, diagnosis, treatment and options. J Contemp Dent Pract. 2013;14(1):123-8. doi :10.5005/jp-journals-10024-1284

4. Cakan D, Canter H, Cakan U, Demir B. Interdisciplinary treatment of a patient with bilateral cleft lip and palate and congenitally missing and transposed teeth. Am J Orthod Dentofacial Orthop. 2014;145(3):381-92. doi:10.1016/j.ajodo.2013.06.021

5. David J. Reisberg, DDS. Prosthetic habilitation of patients with clefts. Clin Plastic Surg. 2004;31(2):353-60. doi: 10.1016/ S0094-1298(03)00135-4

6. Avinash S. Bidra BDS. Esthetic and functional rehabilitation of a bilateral cleft palate patient with fixed prosthodontic therapy. J Esthet Restor Dent. 2012;24(4):235-44. doi: 10.1111/j.17088240.2011 .00485

7. Sato S, Hotta TH, Pedrazzi V. Removable occlusal overlay splint in the management of tooth wear: a clinical report. J Prosthet Dent. 2000;83(4):392-5. doi: 10.1016/S0022-3913(00)70032-
8. Conti PC, Pegoraro LF, Ferreira PM. Procedimento para reabilitação de pacientes com desgaste dental acentuado. Rev Assoc Paul Cir Dent. 1993;47(6):1187-91.

9. Dahl BL. The face height in adult dentate humans. A discussion of physiological and prosthodontic principles illustrated through a case report. J Oral Reabil. 1995;22(8):565-9. doi: 10.1111/ j.1365-2842.1995.tb01050.x

10. Calvani L, MichalakisK, Hirayama H. The influence of full-arch implant-retained fixed dental prostheses on upper lip support and lower facial esthetics: preliminary clinical observations. Eur J Esthet Dent. 2007;2(4):20-8.

11. Rezende AB. Atlas de prótese: sistema de encaixe. São Paulo: Artes Médicas; 2003

12. David R, Burns DMD, Ward JE. Review of attachments for removable partial denture design: Part 1. Classification and Selection. Int J Prosthodont. 1990;3(1):98-102. 